\title{
Green tourism as innovative direction of households' activities in rural areas
}

\author{
Viktoriia Shcherbachenko ${ }^{1 *}$, Liudmyla Zakharkina², Oleksii Zakharkin ${ }^{3}$, Ihor Basantsov $^{4}$ \\ ${ }^{1} \mathrm{PhD}$ in Economics, Senior Lecturer of International Economic Relations Department, Sumy State University, Ukraine \\ ${ }^{2} \mathrm{PhD}$ in Economics, Associate Professor of Department of Finance and Entrepreneurship, Sumy State University; Ukraine. \\ ${ }^{3}$ Doctor of Economics, Professor of Department of Finance and Entrepreneurship, Sumy State University, Ukraine. \\ ${ }^{4}$ Doctor of Economics, Professor of Department of Finance and Entrepreneurship, Sumy State University, Ukraine.
}

\begin{abstract}
The article deals with the challenges and opportunities of the world tourism industry. We consider green (rural) tourism as an innovative direction of households' activities in rural areas. Furthermore, the development of rural tourism can be a factor of the creation of a positive rural area image and it may attract more investment. Rural areas have a rich cultural and natural heritage worldwide. Thus, its diversity may become a huge asset for those who want to develop in rural tourism. We have analyzed the tourist potential of the Sumy region and defined directions for its development. The touristic map was created. Received results can be used to develop municipal and governmental programs that related to touristic services`infrastructure in rural areas.
\end{abstract}

\section{The tourism industry: an overview}

\subsection{Challenges and opportunities of the world tourism industry}

Tourism is a multidimensional, multifaceted economic activity with a strong social element. In 1991, the World Tourism Organization (UNWTO) offered the following definition: tourism is an activity of persons who travel outside their normal environment for a period not exceeding one consecutive year. The aim of it can be leisure, business or others, which not related to activities that paid for from sources at the place of residence [1].

The tourism industry remains a major component of income and employment at the national, regional and local levels. It is estimated that tourism accounts for $10.4 \%$ of world GDP and $10.6 \%$ of world employment in 2018.

Tourism is like a volcano in the sense that demand for it can fluctuate significantly in response to economic cycles, natural disasters, especially to hostilities or rapid political change. For example, the tourism industry in Greece and the Middle East was badly damaged during the Gulf War in 1991. Foot-and-mouth disease in the UK nullified the demand for tourism in 2001. The terrorist attack on the Twin Towers on September 11, 2001 had a significant impact on international tourism, which led to the closure and reduction of several airlines. Today's situation with the global coronavirus pandemic is not known at all, what damage it will cause in the tourism industry.
Tourism is a highly competitive industry. Current trends in tourism take into account the transition to shorter but more frequent vacations; growing interest in tourism in a friendly atmosphere.

\subsection{The development of rural tourism as a factor of rural areas' image}

Compared to the world tourism market, rural tourism of all forms is a relatively small sector due to the fact that the bulk of tourism is still concentrated on the coasts and in cities. If governments and the tourism industry want to develop new regions, they can count on rural areas, which have so far been underdeveloped as tourist areas. The local authorities and other organizations across Europe are counting on rural tourism as a key part of their local development efforts [2].

Rural tourism can be defined as tourism that takes place in a rural context; or as an economic activity that depends on and uses the countryside. Rural tourism offers visitors something different than conventional tourism models [3]. However, rural tourism is not just an alternative to other, more familiar forms: it is a mood according to which tourists are actively looking for recreation in the countryside. The real or imaginary rural life of the region attracts as a contrast to modern urban life [4].

Rural tourism offers renewed contact with nature. It is clear why agritourism, ecotourism and the organization of so-called alternative forms of tourism have become so popular in the last ten years, have received the help of balanced marketing and significant financial support from

\footnotetext{
* Corresponding author: v.shcherbachenko@macro.sumdu.edu.ua
} 
national and regional governments, as well as from the EU. Rural tourism can make a significant contribution to the rural economy. This contribution can be assessed not only in terms of gross national product and employment indicators, but also in more general terms of economic profit.

Rural tourism can diversify the local economy, open new markets for local products and services, provide new sources of income for farmers and those whose livelihoods are threatened by changes in agriculture, and promote new businesses. Tourism can be an "additional crop" in rural areas, changing the balance between primary industries such as agriculture and tertiary or service sectors [5].

In many remote or border areas, local communities and politicians see rural tourism as a major driver of recovery. Tourism can also bring social and cultural benefits to rural areas. It can be a social and cultural contact between the local population and visitors; awareness of the value of the heritage and the need to preserve it will increase both among visitors and the local population; the sense of identity and unity of the local community will be strengthened; local transport, other services will be more fully used, and therefore their viability will increase. That is why tourism in its best form can help rural communities find new opportunities for local economic development, improve their quality of life, preserve heritage and social values [6].

There are also dangers associated with tourism. This is an increase in the cost of utilities for the local population, rising prices for land and housing; labor market imbalance, with a large advantage of seasonal, hourly; people are forced to leave their traditional jobs in agriculture or handicrafts; congestion and overpopulation, which affect the quality of life of local residents; clash of local culture and visitor cultures; increase in crime and antisocial behavior; pollution and depletion of the environment. Perceptions of local identity and selfawareness of residents may also change imperceptibly when local heritage and culture are sold as tourism products.

The lack of information and financial resources hinders the further development of rural tourism. Despite this, in Ukraine, as in other European countries, rural tourism plays an important role in rural development. Development of rural tourism in the perspective of reducing the outflow of human resources from rural areas, diversification of the local economy, as well as expanding the overall range of tourist services offered by Ukraine today.

Rural tourism in Ukraine is to create tools that create modern problems, and this will allow the rural population and motivate them to cooperate, while the residents remain quite native.

At the initial stage, you see that there may not be enough achieved in terms of views, but they provide pure positive forces and offer to make a more effective problem, which is why residents of Ukrainian villages face $[2,3]$.

\subsection{Heritage preservation and management through tourism}

Europe's rural areas have a rich cultural and natural heritage. Moreover, this heritage varies greatly from one region to another, reflecting changes in the geology of the continent, the diversity of climate, wildlife, land usage, the historical development of human settlements, and other factors.

Heritage and its diversity are huge assets for those who want to develop in rural tourism. They offer the tourist a clear contrast to the modern environments of the world created by man; provide a clear, unique place for selfexpression, which allows you to compete in attracting tourists. Historical surroundings, traditions, archeological finds, unique landscapes, wildlife and adventures attract you - all this can help people connect with their origins and individuality, with the world in which they live. They can feel creativity, beauty and freedom.

It is necessary to use these assets for tourism rationally. Tourism is a unique economic sector in which buyers come to the products themselves (while in agriculture it moves to the buyer). This means that the countryside, as a destination, receives visitors and everything that comes with them - cars, buses, sports equipment and more. This can disturb the tranquility of the unique place of the region, its heritage. The environment that surrounds the peasants is a means of agriculture and other economic activities, as well as the main attraction for future tourists. Therefore, in order to achieve rational use, it is necessary to avoid inappropriate or excessive tourism, which can harm the environment, disturb the peace of the inhabitants.

There is a need among the tourists themselves to respect the environment and the heritage of tourist areas. They are aware that tourism must be of a common nature, effectively helping to preserve natural and cultural resources. This is evidenced by the deployment of ecotourism, nature tourism, alternative tourism. In 1994, the World Wildlife Fund identified ecotourism as a respectful trip to natural areas that preserves the environment and protects the well-being of rural people [2].

\section{Analysis of green tourist services in the Sumy region}

Sustainable social and economic development of territories is one of the key priorities of economic policy of Ukraine.

We considered in our previous research [7] that lowbudget types of tourism were distributed widely all over the world, such as environmental, cognitive, sporting health-improvement etc. The development of them needs relatively low investments. The low-budget types of tourism can provide profit fast enough in case of proper organization. Other advantage of this type of business is its environmental direction, which is of current interest.

Ethnographic tourism (agrotourism) also becomes popular in European Union and North America. The specific feature of this type of tourism is that is carried out 
in rural area and provides services by villagers to people on vacations.

However, domestic market of tourist services formation is done slowly enough and unsystematic. Existent scientific works mostly examine specific types of tourism marketing and do not allow system to estimate and define the ways to realize tourist services market of the territory.

An analysis was conducted by the following scheme (Fig.1). Let us perform qualitative analysis of specific constituents potential of tourist services market in the Sumy region [7].

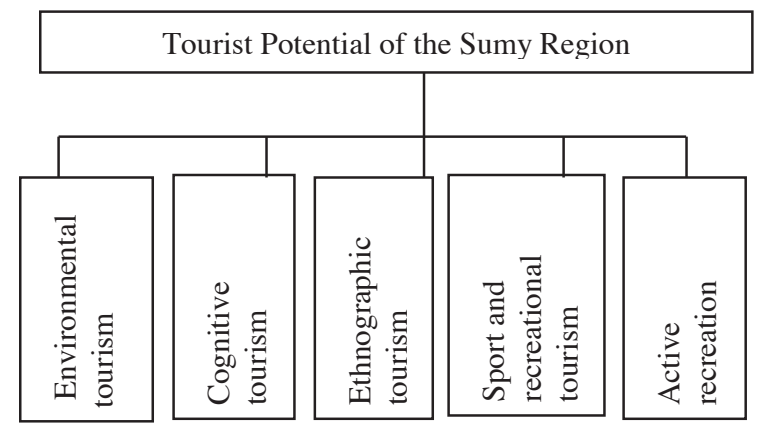

Fig. 1. Constituents of tourism potential of the Sumy region.

We have choosen method of in-depth interview To study the prospects of tourism development in the Sumy region. In order to better and more fully understand the problems, seven respondents were interviewed: the head of the Sumy regional branch of the Union for the Promotion of Rural Green Tourism in Ukraine, the owner of the green estate "Vakulina Baika" in the village Bezdryk, Sumy district, the owner of the estate "Northern Forest" in the village Zholdaks of Konotop district, director of the travel agency "Sumy tour salon", three ordinary citizens who are residents of the Sumy region and who prefer outdoor activities.

The survey was conducted in a private meeting with the respondents by prior arrangement. An audio recording of the conversation was made on a dictaphone, after which a transcript of the interview was made.

Moreover, we conducted a questionnaire among existing and potential consumers, intermediaries, i.e. persons who make decisions about the purchase of services or have an influence on the purchase process. The purpose of the questionnaire was:

1) analysis of prospects for tourism development in Sumy region;

2) determine the chances of Sumy region to provide rural tourism services;

3) study of the target audience of households receiving tourists in rural areas;

4) determining the motives of potential customers that prompted them to choose a place of rest;

5) finding out exactly what services tourists would like to receive during their stay in the estates.

The target audience consists men and women aged 18 to 65 years, who prefer an active type of rest and live in the Sumy region and in cities-neighbours (Kharkiv, Poltava, Chernigiv).

\subsection{Environmental tourism}

The Sumy region is an oblast in the northeastern part of Ukraine. It is situated on a border of the Bryansk Oblast (Russia) on the northeast, the Kursk Oblast (Russia) on the east, the Poltava on the southwest, the Kharkov Oblasts on the south, and the Chernihiv Oblast on the west.

The oblast is located within the limits of two physicalgeographical areas - polissya and to forest-steppe. The climate of area is moderate continental, with a warm summer and moderate cold winter. Over 300 rivers flow for territories of oblast. All of them belong to the pool of Dnipro. The biggest rivers are Desna, Seym, Sula, Psel, Vorskla. 33 large lakes, 1660 ponds and reservoirs are located in the oblast [8].

Naturally, protected fund of area is presented by unique and natural territories and subjects preserved best way, almost of all types and categories. Today their amount reached 208 pieces and makes 158164,27 hectares or $6,64 \%$ of general territory of the Oblast [8]. It is one of the best indexes in Ukraine.

There are a national natural park, protected woodland branch, 10 nature reserves, 3 nature monument, 2 park-monuments of landscape art of national value; 2 regional landscape parks, 29 protected natural boundaries, 54 nature reserves, 62 nature monuments, 19 parkmonuments of landscape art and 1 botanical garden of local value [8]. Description of basic natural territories protected by state of Sumy region is given in the Table. 1 .

Sumy region has everything necessary for environmental tourism development. Objects presented in the Table 1 can be interesting for variety of persons, who are interested in natural landscapes and territories which was saved on Sumy region and which are hardly available in European Union countries.

\subsection{Cognitive tourism in the Sumy region}

The Sumy region has unique historical and cultural legacy - almost 1,5 thousands of historical value spots, 780 archaeology, 102 monuments of monumental art and 373 architecture pieces. Wonderful pieces of garden-parks and architecture (t. Sumy, v. Khotin, v. Kiyanicya, v. Kuyanivka, v. Barrels, v. Volokitino), monasterial complexes (Movchanskiy, Safroniivskiy, Glinskiy and etc.) were preserved.

Interesting exhibits of regional museums will attract tourists in the following cities: Sumy, Glukhiv, Okhtyrka, Romny, Shostka, Konotop. House-museum of A.P. Chekhov, located in the suburbs of Sumy city, named Luka; museum exposition of Petro Tchaikovsky in Nizy village, nearby Sumy; the expositions of Sumy Art Museum (one of the best in Ukraine) name by $M$. Onatskyi and Lebedinskiy Art museum present masterpieces of international level artists.

The unique objects of civil architecture, which can be seen in Sumy region, are the following:

- Round Court in Trostianets, built in 1749 , as a riding hall of circus and for economic necessities; 
- Museum of Local Lore (House of Sumy Zemstvo);

- House of Nobiliary collection in Glukhiv, presently local Museum of Regional Ethnography.

Table 1. Basic wildlife territories of the Sumy region.

\begin{tabular}{|c|c|c|c|c|}
\hline $\mathrm{N}$ & Object name & $\begin{array}{c}\text { Area, } \\
\text { (hectare) }\end{array}$ & Type & District \\
\hline \multicolumn{5}{|c|}{ Protected woodlands } \\
\hline 1 & $\begin{array}{l}\text { "Mikhaylivska } \\
\text { virgin soil" }\end{array}$ & 202,48 & $\begin{array}{l}\text { separation } \\
\text { of the } \\
\text { Ukrainian } \\
\text { steppe } \\
\text { natural } \\
\text { preserve }\end{array}$ & Lebedinskiy \\
\hline \multicolumn{5}{|c|}{ National natural parks } \\
\hline 1 & $\begin{array}{l}\text { "Desnyansko - } \\
\text { Starogutskiy" }\end{array}$ & 16215,1 & $\begin{array}{c}\text { national } \\
\text { natural park }\end{array}$ & $\begin{array}{l}\text { Seredino- } \\
\text { Budskiy }\end{array}$ \\
\hline \multicolumn{5}{|c|}{ Sanctuaries of national value } \\
\hline 1 & $\begin{array}{c}\text { "Large } \\
\text { coniferous } \\
\text { forest" }\end{array}$ & 1231,0 & forest & Shostkinskiy \\
\hline 2 & "Shaliginskiy" & 2868,1 & landscape & Glukhivskiy \\
\hline 3 & $\begin{array}{l}\text { "Seredneseymsk } \\
\text { iy" }\end{array}$ & 2020,8 & landscape & $\begin{array}{l}\text { Burinskiy, } \\
\text { Bilopilskiy, } \\
\text { Putivlskiy }\end{array}$ \\
\hline 4 & $\begin{array}{c}\text { "Bath-house } \\
\text { ravine" }\end{array}$ & 2020,8 & botanical & Sumskiy \\
\hline 5 & "Cranberry" & 258,0 & $\begin{array}{c}\text { ornithologic } \\
\text { al }\end{array}$ & Sumskiy \\
\hline 6 & $\begin{array}{l}\text { "Andriyashivsko } \\
\text {-Gudimivskiy" }\end{array}$ & 1509,6 & hydrologic & Romenskiy \\
\hline 7 & "Bilovodskiy" & 1515,7 & hydrologic & Romenskiy \\
\hline 8 & "Klimentivskiy" & 1007,5 & hydrologic & Okhtirskiy \\
\hline 9 & "Bakirivskiy" & 2606,0 & hydrologic & $\begin{array}{c}\text { Okhtirskiy, } \\
\text { Trostyaneckiy, } \\
\text { Velikopisarivs } \\
\text { kiy }\end{array}$ \\
\hline $\begin{array}{l}1 \\
0 \\
\end{array}$ & $\begin{array}{c}\text { "Khukhryanskiy } \\
\text { " }\end{array}$ & 4591,6 & hydrologic & Okhtirskiy \\
\hline \multicolumn{5}{|c|}{ Nature monument of national value } \\
\hline 1 & $\begin{array}{l}\text { "Apple-tree- } \\
\text { colony" }\end{array}$ & 0,06 & botanical & Kroleveckiy \\
\hline 2 & $\begin{array}{c}\text { "Natural } \\
\text { boundary } \\
\text { Boromlya" }\end{array}$ & 55,0 & zoological & Konotopckiy \\
\hline 3 & $\begin{array}{l}\text { "Shelekhivske } \\
\text { Lake " }\end{array}$ & 7,0 & hydrologic & Lebedinskiy \\
\hline
\end{tabular}

One of the oldest Cossack churches in Ukraine is the Mykolaiv church in Glukhiv (in 1693). Sacral architecture of Sumy region has unique buildings - Voskresenska church and Spaso-Preobrazhenskiy cathedral in Sumy, church of Mykola Cossack in Putivl, Svyatodukhivskikh cathedral in Romni, Pokrovskiy Cathedral Complex in Okhtyrka, Trekh-Anastasiyivska church in Glukhov and others.

Our land gave a domestic and world culture many notable talents, writers and poets, such as Pantelejmon Kulish, Pavlo Grabovskiy, Oleksandr Oles, Ostap Vishnya, Ivan Bagryanyi, Oleksa Yushchenko; artists Anton Losenko, Hryhoriy Stetsenko, Georgiy Narbut, Fedir and Vasyl Krichevski, Mikolo Murashko; sculptor Ivan Kavaleridze; composers Maksym Berezovskiy, Dmytro Bortnyanskiy, singers Boris Gmirya, Petro Bilinnik, Anatoliy Mokrenko; linguist Oleksandr
Potebnya, physicist Abraham Ioffe and other famous Ukrainians [8].

\subsection{Potential of ethnographic, sports and recreational tourism and rest}

Products of folk masters of Sumy region will not leave indifferent the guests of our area: unique Kroleveckiy towel, wares of Boromlyanska wicker furniture factory, souvenirs of Sumy porcelain factory, plant "Veres". Festivals and competitions (Table 2) are also of interest as our area residents really enjoy them. They are also visited by nearby areas inhabitants with pleasure. This testifies possibilities of ethnographic tourism "tied" to certain events (like Sorochinskiy fair).

There are numerous places which will be able to attract tourists from the different cities of Ukraine and from abroad. Settlements and towns of rural type prevail on Sumy region. The idea of ethnotourism is pending for our region, as village residents face with unemployment and necessity to find source of income for themselves and their families is acute [7].

Plenty of forests, lakes and rivers can be of interest for sports and recreational tourism admirers. Sumy region territory can provide everything for rafting, living in tent camps on the bank of the river or lake, sport fishing, lakes wind-driven sport, cross-country skiing, etc. In case proper infrastructure development, it is possible to create stationary tourist locations: forest, water, steppe and so on.

Large horse-breeding farm and hippodrome are located on the picturesque area close to Sumy. Sporting competitions and events are regularly conducted there. All interested persons can participate, in particular: journeys around the area in horse cart or on sledges (in winter time).

It should be marked that development of recreationaltourist complexes corresponding international standards, in addition to that it can become the substantial source of foreign currency, is able to bring a considerable benefit, meaning considerable portion of population involvement in tourists service and preservation and expansion of the unique natural territorial complexes, environmental status improvement.

Tourist sightseeing routes being developed will assist to create terms for the study of historical and cultural legacy of the area, acquaint with natural sights of edge, they will able to provide recreation for various categories of population, will provide possibility for the Sumy region to reach wide informative space, honorary declare itself on a national and international arena not only with informational-advertising means, but with specific offers of competitive tourist sightseeing products [9]. Thus, Sumy region has everything to develop rout-cognitive and ethnographic tourism.

The results of conducted analysis allowed selecting regions and settlements of the Sumy region suitable to develop various types of tourism (Fig. 2). 
Table 2. Cultural and art events which takes place in the Sumy region.

\begin{tabular}{|c|c|c|c|}
\hline Event & Term & Place & Participants \\
\hline $\begin{array}{l}\text { All-Ukrainian } \\
\text { festival } \\
\text { „Cossack } \\
\text { rodoslav” }\end{array}$ & $\begin{array}{l}\text { July, } \\
\text { annually }\end{array}$ & $\begin{array}{l}\text { Shapovalivka } \\
\text { district of } \\
\text { Konotop }\end{array}$ & $\begin{array}{l}\text { Vocal } \\
\text { masculine } \\
\text { groups. }\end{array}$ \\
\hline $\begin{array}{l}\text { All-Ukrainian } \\
\text { rural festival of } \\
\text { arts } \\
\text { „Boromlya” }\end{array}$ & $\begin{array}{l}\text { annually } \\
\text { during the } \\
\text { last ten- } \\
\text { day period } \\
\text { of August }\end{array}$ & Trostianets & $\begin{array}{l}\text { Leading artistic } \\
\text { collectives and } \\
\text { soloists, young } \\
\text { artists of the } \\
\text { stage in a } \\
\text { vocal, } \\
\text { choreographic, } \\
\text { instrumental, } \\
\text { colloquial } \\
\text { genre. }\end{array}$ \\
\hline $\begin{array}{l}\text { All-Ukrainian } \\
\text { literature-art } \\
\text { festival } \\
\text { "Krolevecki } \\
\text { towels" }\end{array}$ & $\begin{array}{l}\text { November, } \\
\text { annually }\end{array}$ & Krolevets & $\begin{array}{l}\text { Poets and } \\
\text { writers, artists } \\
\text { and masters of } \\
\text { decoratively } \\
\text { applied arts, art } \\
\text { critics, } \\
\text { professional } \\
\text { and amateur } \\
\text { artistic } \\
\text { collectives and } \\
\text { separate } \\
\text { performers } \\
\text { from the } \\
\text { different } \\
\text { regions of } \\
\text { Ukraine, } \\
\text { Russian } \\
\text { Federation and } \\
\text { other countries } \\
\text { of CIS. }\end{array}$ \\
\hline $\begin{array}{l}\text { All-Ukrainian } \\
\text { cossack } \\
\text { holiday of } \\
\text { „Kalnisheva } \\
\text { rada” }\end{array}$ & $\begin{array}{l}\text { October, } \\
\text { annually }\end{array}$ & $\begin{array}{l}\text { Pustoviytivka } \\
\text { Romenskiy } \\
\text { district }\end{array}$ & $\begin{array}{l}\text { All people, } \\
\text { who wish to } \\
\text { respect } \\
\text { memory of the } \\
\text { last ataman of } \\
\text { Zaporizhian } \\
\text { Sich - Petro } \\
\text { Kalnishevskiy. }\end{array}$ \\
\hline $\begin{array}{l}\text { Regional } \\
\text { festival-contest } \\
\text { of the } \\
\text { Ukrainian song } \\
\text { the name of } \\
\text { Boris Gmiri } \\
\text { "For the name } \\
\text { of glorious } \\
\text { fellow } \\
\text { countryman" }\end{array}$ & $\begin{array}{l}\text { August, } \\
\text { annually }\end{array}$ & Lebedyn & $\begin{array}{l}\text { Vocal duets, } \\
\text { trios, quartets, } \\
\text { vocal bands } \\
\text { and separate } \\
\text { performers } \\
\text { from the } \\
\text { different } \\
\text { regions of } \\
\text { oblast, } \\
\text { Ukraine, other } \\
\text { countries, } \\
\text { regardless of } \\
\text { their } \\
\text { nationality, } \\
\text { citizenship, and } \\
\text { without age-old } \\
\text { limitations. }\end{array}$ \\
\hline $\begin{array}{l}\text { Regional } \\
\text { festival of folk } \\
\text { instrumental } \\
\text { music "Merry } \\
\text { musician" }\end{array}$ & May & $\begin{array}{l}\text { Zhovtneve, } \\
\text { Bilopilskiy } \\
\text { district }\end{array}$ & $\begin{array}{l}\text { Bands of folk } \\
\text { musicians, } \\
\text { bands of folk } \\
\text { instruments, } \\
\text { triple } \\
\text { musicians, } \\
\text { separate } \\
\text { performers of } \\
\text { folk } \\
\text { instrumental } \\
\text { music. }\end{array}$ \\
\hline
\end{tabular}

\begin{tabular}{|l|l|l|l|}
\hline $\begin{array}{l}\text { Regional } \\
\text { child's festival- } \\
\text { competition of } \\
\text { performers of } \\
\text { modern } \\
\text { vaudeville } \\
\text { song "Magic } \\
\text { key" }\end{array}$ & April & Yampil & $\begin{array}{l}\text { Children and } \\
\text { teenagers, who } \\
\text { are performers } \\
\text { of modern } \\
\text { vaudeville song }\end{array}$ \\
\hline $\begin{array}{l}\text { All-Ukrainian } \\
\text { festival of wind } \\
\text { music "Furnace } \\
\text { of } \\
\text { Constitution" }\end{array}$ & $\begin{array}{l}\text { end of } \\
\text { June, } \\
\text { annually }\end{array}$ & Sumy & $\begin{array}{l}\text { Brass bands are } \\
\text { from the } \\
\text { different cities } \\
\text { of Ukraine, and } \\
\text { also guest from } \\
\text { other countries }\end{array}$ \\
\hline $\begin{array}{l}\text { Interregional } \\
\text { Miropilskiy } \\
\text { fair }\end{array}$ & $\begin{array}{l}\text { middle of } \\
\text { August, } \\
\text { annually }\end{array}$ & $\begin{array}{l}\text { Miropillya, } \\
\text { Krasnopilskiy } \\
\text { district }\end{array}$ & $\begin{array}{l}\text { Representatives } \\
\text { of } \\
\text { agroindustrial } \\
\text { enterprises, } \\
\text { trade, } \\
\text { restaurant } \\
\text { business, folk } \\
\text { skilled } \\
\text { craftsmen from } \\
\text { all districts of } \\
\text { Sumy region } \\
\text { and other areas } \\
\text { of Ukraine. }\end{array}$ \\
\hline & & &
\end{tabular}

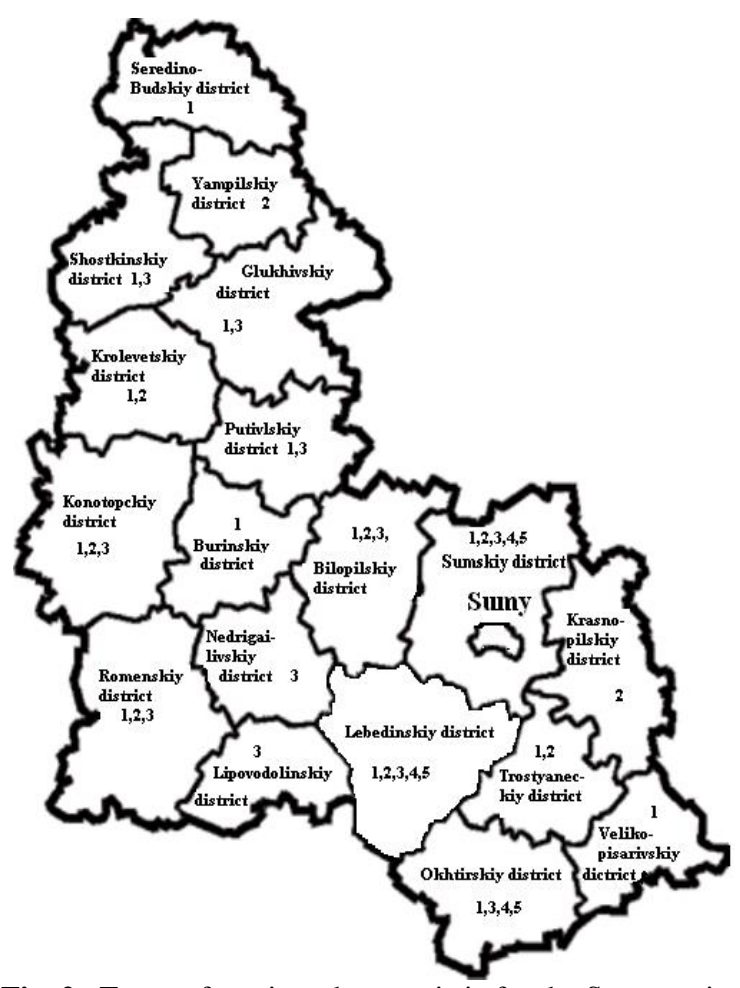

Fig. 2. Types of tourism characteristic for the Sumy region. Symbols legend in the figure 2: 1 - environmental tourism; 2 ethnographic tourism; 3 - rout-cognitive tourism; 4 - sanatoriumrecreational tourism; 5 - sport and recreational tourist, including: water, walking tours, sports fishing, hunting, equestrian and others.

\section{Conclusion}

In conclusion, we have investigated challenges and opportunities of modern world tourism industry. Based on this, we see that new directions are needed for the development of this industry. In addition, tourism can be a driver for rural development. Thus, we conducted an 
analysis of natural and resource potential to provide green tourism services of the Sumy region. We have chosen this area because it is our motherland.

The results of executed research can be drawn on for the ground of decisions about creation (modernization) the proper infrastructure for the rant of tourist services in the Sumy region: in programs of social and economic development, marketings programs of forming and development of the image of the Sumy region as region friendly to tourism, and also informing the system normative-legal certificates which stimulate the development of tourist business.. The offered method can be used to analyse sufficientness already present base (in the that or other region of Ukraine on the whole or its areas) for acceptance of the proper amount of domestic or foreign tourists taking into account their queries and tastes.

It is expedient to develop such directions of tourism as environmental, ethnographic, rout-cognitive, and also sports and recreational. Authors come into the special notice on development of new, both for Ukraine in general and for our region in particular, directions of tourism ecological and ethnographic.

\section{Acknowledgement}

This work was supported by the Ministry of Education and Science of Ukraine (Project No. 0117U003922 «Innovative drivers of national economic security: structural modeling and forecasting»)

\section{References}

1. The World Tourism Organization. Retvitered from: https://www.unwto.org/

2. Maevsky J. Agrotourism. Lviv, 82 (2005).

3. Gorishevsky P. Rural green tourism: history and current state. Rural green tourism. Ivano-Frankivsk, 15-29 (2003).

4. Kuzo N. Je., Kosar N. S Marketing support of rural green tourism development in Ukraine. Marketing and Management of Innovations. Vol 2. 369-381 (2017). DOI: $10.21272 / \mathrm{mmi} .2017 .2-34$

5. Kiral'ova A., Hamarneh I. Local Gastronomy as a Prerequisite of Food Tourism Development in the Czech Republic. Marketing and Management of Innovations. Vol 2. 15-25 (2017) DOI: 10.21272/mmi.2017.2-01

6. Krajcik V., Kljucnikov, A., Rihova E. Innovative Sharing Economy's Business Models in Tourism: Case of Airbnb in Prague. Marketing and Management of Innovations. Vol 2. 108-117 (2019) DOI: $10.21272 / \mathrm{mmi} .2019 .2-10$

7. Shcherbachenko V., Illyashenko S. Prospects Assesment of Tourism Services Market in Sumy region. Sustainable development. Vol 3. $17-21$ (2012).

8. Ministry of Environmental Protection of Ukraine. State Department of Environmental Protection in Sumy region. Retvitered from: http://www.eco.sumy.ua/
9. Sumy tourist. Retvitered from: http://www.tour.sumy.ua/history.php

10. Rural green tourism. Union for the Promotion of Rural Green Tourism in Ukraine. Retvitered from: http://www.greentour.com.ua/ukrainian/department/ $\underline{23}$ 